This paper is the accepted version forthcoming in European Journal for Philosophy of Science, for the topical collection on 'teaching philosophy of science to students from other disciplines'.

\title{
A Dialogue on the Ethics of Science: Henri Poincaré and Pope Francis
}

\author{
By: Nicholas Danne
}

\begin{abstract}
:
To teach the ethics of science to science majors, I follow several teachers in the literature who recommend "persona" writing, or the student construction of dialogues between ethical thinkers of interest. To engage science majors in particular, and especially those new to academic philosophy, I recommend constructing persona dialogues from Henri Poincaré's essay, "Ethics and Science" (1963/1913), and the non-theological third chapter of Pope Francis's (2015) encyclical on the environment, Laudato si. This pairing of interlocutors offers two advantages. The first is that science students are likely to recognize both names, since Poincaré appears in undergraduate mathematics and physics textbooks, and because Francis is an environmentalist celebrity. Hence students (in my experience) show more interest in these figures than in other philosophers. The second advantage is that the third chapter of Laudato si reads like an implicit rebuttal of Poincaré's essay in many respects, and so contriving a dialogue between those authors both facilitates classroom discussion, and deserves attention from professional ethicists in its own right. In this paper, I present my own contrived dialogue between Francis and Poincaré, not for assigning to students as a reading, but as a template for an effective assignment product, and as a crib sheet for educators to preview the richly antiparallel themes between the two works.
\end{abstract}

\section{Main Text:}

\section{NAME-DROPPING FOR NON-MAJORS}

Often a science student's introduction to philosophy begins by their enrolling in an ethics class required for graduation. I have taught that class several times, and as a degreed engineer myself, I feel at home among the intensely analytical students who have zero tolerance for "fluff," a key indicator of "fluff" being a subject matter's lack of governing equations, ${ }^{1}$ or its imperviousness to experimentation and measurement. To break the ice, then, I sometimes attempt to engage my students under the guise of not-doing-philosophy. One form of this guise, profitably exploited in advertising, is name-dropping. I sometimes notice eye-contact from the most aloof of students when I mention names that they know, and which their own peers and major professors respect.

\footnotetext{
${ }^{1}$ When I was an engineering undergraduate, for example, I disliked equation-free introductory biology. I felt like I had to take the professor's and textbook's word for everything.
} 
Mechanical and aerospace engineering students, in particular, devote long hours to studying Mach-speed aerodynamics and the formation of Mach cones, perhaps without realizing that Ernst Mach was an influential philosopher of science, who studied Isaac Newton's laws not only to apply useful equations, but to interpret the equations in a deeper and more responsible sense than engineering textbooks are likely to explicate. The same goes for Henri Poincaré, a name gracing the mathematics and physics textbooks of all engineering students. Who would have thought that Poincaré would have dabbled in ethics? But dabble he did, writing an accessible and opinionated polemic, "Ethics and Science," published posthumously in 1913 (Poincaré 1963). I employ such revelations as one vehicle for convincing science students to respect philosophy, at least a little bit.

My purpose in this essay, however, is to engage ethics-of-science educators rather than students. For there is another prominent name that science students recognize, Time magazine's 2013 "Person of the Year" and celebrated environmentalist, Pope Francis. What I seek to highlight in this essay is the remarkable covert dialectic between Poincaré's "Ethics and Science" (hereafter ES) and Pope Francis's (2015) encyclical on the environment, Laudato si (hereafter $L S$ ). I say "covert" rhetorically, having no proof that Francis read Poincaré, or is responding a century later to his polemic; but in many ways the non-theological third chapter of $L S$ reads like a detailed rebuttal of $E S$, and I have found this dialectic profitable to examine with science students.

Profitable how? Specifically, as a creative format and change of pace; a departure not only from the analysis paper and ethics speech, but from the rigorous analytical methods needed to complete those assignments well. I notice, in other words, that some first-time philosophy students harbor a traditional or overtly religious notion of morality, and part of my task in 
cultivating a pluralistic student mindset for recognizing areligious normative paradigms like deontology, utilitarianism, and virtue in the workplace is shepherding students away from their comfortable traditions. Hence, I assign the Francis-Poincaré dialogue after mid-term, to allow students to "spring back" to what might be their ethical comfort zone, to let them relate without paradigmatic rules to two vibrant texts that seem to lock horns across a century of scientific achievement. I intend the student to absorb the two messages at face value, and then to intuit through contrived dialogue the message that most resonates with the student, or to introduce a moral claim that one of the interlocutors might plausibly advance against the other.

The learning objectives for this assignment are twofold. First, it affirms a place for moral intuition and exploration alongside the normative-paradigmatic reasoning drilled in the first half of the term; for by mid-term, some students may recognize limitations or shortcomings inherent to a given paradigm, ${ }^{2}$ and desire to formulate in non-theoretic language what is immoral within a given scenario. Secondly, the exercise tacitly allows students to discover for themselves how much they like (or dislike) resorting to traditional ethical intuitions after being trained in classical normative paradigms. Recognizing where there is overlap between the old and new systems, and where there is clearly no overlap, forms an important dimension of the critical ethical thinker, in my view. Specifically, recognizing this overlap can lead to a self-check against unwarranted bias, although I think that systematic bias is too large a topic to shoehorn into the dialogue assignment itself, and should be taught in an auxiliary lesson.

Thus, to clarify, the mock dialogue that I offer in section III is not one that I would assign any students to read. It is rather a template for the finished product of an assignment that is fun to grade and intuition-friendly to compose. My mock dialogue is noticeably inelegant, stilted,

\footnotetext{
${ }^{2}$ An excellent catalog of these limitations, accessible to students, appears in the introduction of Daly (2016).
} 
and somewhat facetious for consisting mostly of direct quotes; but for reasons that I explain in section IV, this format is by design. Before presenting my dialogue, I provide in section II some background on the texts by Francis and Poincaré, to anticipate the ethical themes likely to emerge from them.

\section{LAUDATO SI AND THE ETHICS OF SCIENCE}

Understanding my mock dialogue requires prior contextualization. The philosophy instructor should be aware, for example, that Laudato si has been widely acclaimed as an ecumenical and even humanist call to care for the environment, a call issued not merely to maximize utilitarian outcomes, or to apply theology, or to signal existential despair in high places. The encyclical instead renders care for the environment a matter of ethical uprightness, emphasizing the personal emptiness $(L S \text {, para. 113) })^{3}$ to be found in people of all creeds and walks of life who relegate the natural environment to an object of consumerist control. This emptiness, this character fault, allegedly afflicts everyone, from wealthy financiers, to the exploited poor, to even some environmentalists who rely too confidently on technological solutions to pollution, resource scarcity, and climate change ( $L S$, Chapter $3, \S \S \mathrm{I}-\mathrm{II})$. One of the main ethical takeaways of $L S$ finds independent expression by other authors (e.g., Vallor 2015), that technology is not a morally neutral device; it instead transfers immense power into the hands of a few ( $L S$, para. 104-112), whom according to Francis have positioned society on a trajectory of emptiness ( $L S$, para. 109) and perdition.

Some philosophers share my view that one of the main objectives of Laudato si is the moral betterment of the agent who consumes resources (Weidel 2019; McGuigan 2019, 402;

\footnotetext{
${ }^{3}$ The abbreviation "para." indicates paragraph number, not to be confused with section number ("§") or chapter, in $L S$.
} 
Iheka 2017, 253-254; Sedmak 2016, §1). Others praise the encyclical as a timely advance in postsecular environmentalism (Handley 2016; Szerszynski 2016), or relatedly, point out the inclusive array of non-Vatican sources in the document's footnotes (Sedmak 2017, 942-943). Alternative analyses conclude that $L S$ renders the environment "ontologically significant" for ethical appraisal (Weidel 2019,31), and helps the scientist or engineer promote the "common good" over the "greater good" (Punzi 2018), while other authors suggest interpretations of $L S$ in terms of "media theory" (Dettloff 2017, 932) and St. Francis of Assisi's Canticle of the Sun (Szerszynski 2016). Some critics, on the other hand, dismiss the encyclical as anti-modernist (Reno 2015).

As I intimated in section I, my objective is neither to promote nor undermine particular claims from $L S$, but only to briefly square it in all its richness with $E S$, which I now also contextualize. Poincaré's renown as a physicist and mathematician has lasted from his day to ours, and his influence on the philosophy of science also remains significant. ${ }^{4}$ His foray into ethics in $E S$, on the other hand, appears largely independent of his better-known work, ${ }^{5}$ since in $E S$ he defends the value-free purity of science, and the logical distinctness of ethics and science as disciplines (Barrotta 2018). Poincaré's (1963) curious addition to these theses is an inprinciple identity between the moral fruits of scientific and ethical practice. While he refuses in Humean fashion to derive "ought" claims from "is" claims, ${ }^{6}$ Poincaré (1963) argues that the

\footnotetext{
${ }^{4}$ Particularly with respect to his conventionalism (Ivanova 2015; Ben-Menahem 2006) and structural realism (McArthur 2006; Chakravartty 1998; Zahar 1996; Worrall 1989).

${ }^{5}$ Some might disagree with me, and object that Poincaré's Kantian conventionalism about science grounds or establishes a conventionalism about ethics. As scientists pursue the beautiful order that " pure intelligence can grasp"' (Ivanova 2015: 85, n. 13; cf. Poincaré 1963: 109), in other words, so ethicallyminded agents in Poincaré's (1963) account pursue an identically beautiful and reasonable order of action and behavior. I bypass in this paper the possible Kantian motivations for $E S$.

${ }^{6}$ Barrotta (2018) supports my reading of Poincaré (1963) as Humean.
} 
scientific practice trafficking entirely in "is" claims serves to fulfill moral norms; a conclusion for which some have criticized $E S$ as inconsistent (Kelsen 1991).

Thus, while remaining neutral on the ethical soundness of ES, I find it sufficiently provocative to engage philosophical novices without flattening them. Important to this end is that I broach the value-laden-ness of science to my students, prior to the dialogue assignment. Whether or not my class debates the value-neutrality of science, my standard assignments (analysis papers, ethics speeches) presuppose that parties to historical engineering disasters held moral and non-moral values, and I require students to identify those values and supply evidence that they were held. Debating or defending Poincaré at the ground level of the value-neutrality question could succeed in a student dialogue, but I do not see that exchange as essential to the assignment, and it does not occur in my example of section III. ${ }^{7}$

This dialectical point suggests another important one, however, which could arise so often as to trivialize some dialogues. The insight is that perhaps technological development and application are perspicuously more value-laden (involved as they are with entertainment and leisure) than are the pure sciences of chemistry and physics, in the last century. Because Francis writes predominantly on the ethics of technology (but also mentions "science" to a fair extent), ${ }^{8}$ and because Poincaré scarcely if at all mentions technology, the trivial conclusion looms that both parties are right: the ethical values that producers and consumers of technology have overlooked (according to Francis) simply do not emerge for the pure scientist to overlook (vindicating Poincaré). ${ }^{9}$ In response, I take the defeasible stance that even small improvements

\footnotetext{
${ }^{7}$ I thank an anonymous reviewer for pressing me on the importance and pedagogical difficulty of undermining the value-neutrality of science generally.

${ }^{8}$ Francis's references to science in $L S$ include paragraphs 62 (quoted in section III), 63, 102-103, 106 (quoted in section III), 107, 110, 113 (quoted in section III), 114 (quoted in section III), 131-133, 135$136,143,183,186,188$, and 199-201.

${ }^{9} \mathrm{I}$ thank an anonymous reviewer for a similar version of this objection.
} 
in much of the technology that Francis mentions (airplanes, skyscrapers, medicine) require relatively substantial and extensive progress in the pure sciences, such that to deny outright the cross-implications of Francis and Poincaré's messages is simply naive. ${ }^{10}$ Of course, to insert Poincaré and Francis into dialogue at all, one cannot idly compare scientist ethics (Poincaré) with producer and consumer ethics (Francis). But because neither author writes exclusively of those respective groups, my blurring of science-technology and scientist-producer-consumer implications appears justified for a first-order exchange. ${ }^{11}$ I also acknowledge that there exist insightful and detailed philosophical accounts of how the ethics of science and technology differ (Franssen, Lokhorst, and van de Poel 2018, §2.2), and of how scientific and moral "errors" might be inextricably linked (Condorcet 1976); ${ }^{12}$ while analyzing Francis and/or Poincaré with a view to these theses could be rewarding, I am more interested in letting students' intuitions drive their engagement with the celebrity names they recognize, for reasons that I postpone yet again to section IV.

In the meantime, I recommend some ground rules about which arguments not to level against Poincaré. For Poincaré can sound naive and insensitive in his polemic, writing as he does from an early twentieth century perspective. When he quips, for example, that "Morality has nothing to fear from a science which is motivated by a true experimental spirit" (Poincaré 1963, 110), I expect my students to do more than criticize from a position of hindsight. Aware as we are of the horrors of human experimentation in World War II concentration camps, or in the Tuskegee Syphilis Study (Nix 2019), I expect my students to develop the more difficult and

\footnotetext{
${ }^{10}$ In the automotive industry, for example, full-time ceramic scientists spend years laboring for a few percentage points of increase in ceramic dielectric strength, and implementing this new material in turn requires double-digit iterations of spark plug prototypes for trial-and-error experimentation on an engine.

${ }^{11}$ I propose in section IV some discussion questions about the appropriateness of this blurring.

${ }^{12}$ I thank an anonymous reviewer for this Condorcet reference.
} 
mature claims that Poincaré's "experimental spirit" thesis always or usually yields net negative outcomes, or that it inherently possesses a blind spot about rights or personal character, etc. ${ }^{13}$ One genuine debate that I try to elucidate in my dialogue is that between Francis's warnings about technology's deleterious effects on our character, and Poincaré's counter-claim that scientific practice requires and inculcates good character. Of course, readers might not like the winner that I pick, or the arguments that I counterpose, but reconciling the two readings or providing "the right message for students to grasp" is not my purpose; the relevance of celebrity opinion for contemporary problems is my purpose, and I expect the disagreements that celebrity opinion is bound to engender. ${ }^{14}$ Now please enjoy, as far as possible, how I have combined the two texts.

\section{THE DIALOGUE}

\section{A jail cell somewhere in Europe}

P: What brings you in ${ }^{15}$

F: I was picketing the expansion of an air-conditioner factory. Then a policeman nabbed me for giving a homeless man a sandwich.

P: I heard about that factory. It's going to have a terrific R\&D wing.

\footnotetext{
${ }^{13}$ A different rule that instructors might enforce is a prohibition on theological skirmish dialogues. Poincaré writes brashly against religion in $E S$, and Francis in $L S$ provides plenty of material for replies. I dabble lightly with the theological in my dialogue, recognizing that this angle can steer a philosophy course off track.

${ }^{14}$ By "celebrity opinion," I do not mean "untutored ethical opinion." Francis has formal training in ethics, and for all I know, Poincaré might have also.

${ }^{15} \mathrm{P}=$ Poincaré, with parenthetical citations indicating page numbers of Poincaré (1963); F = Francis, with parenthetical citations indicating paragraph numbers of Laudato si.
} 
F: Keen choice of words. In one sense, we are "right to rejoice" in technological advances, because they are human creativities (para. 102), but our "technological development has not been accompanied by a development in human responsibility, values and conscience" (para. 105). Humankind's interpersonal and environmental violence is interlinked, and not a little terroristic.

P: What are you talking about? Man's problems are man's, and science if anything makes him better. ${ }^{16}$ Hopefully you do not imply something deeper but quite illogical, that the "indicative" enterprise of science has any bearing on the "imperative" claims of ethics (104). The two domains are very different. "There cannot be .. . [an] immoral science" (104).

F: No, I am neither calling science immoral, nor disparaging indicative disciplines. Technology has obviously "remedied countless evils" (para. 102), and I happen to find an "aircraft or a skyscraper" to be things of "beauty ..." (para. 103). The Church that I serve, moreover, "does not presume to settle scientific questions or to replace politics" (para. 188). But surely your sweeping claim that science makes us better needs qualification!

P: I don't see how your objection would go, for in many ways, science can “exercise an indirect influence" — and a good one - on morality (104). "Science keeps us in constant relation to

\footnotetext{
${ }^{16}$ An anonymous reviewer objects that this reading of Poincare is too strong, and unjustified by the remainder of the present main-text paragraph. As the full text of Poincaré (1963) conveys, however, and as I intend the remainder of section III to convey, Poincaré's polemic is an overt and sustained defense of the claim that 'science, if anything, makes us better' (quoting my paraphrase). The brazenness of Poincaré's thesis motivates my selecting it for undergraduates.
} 
something which is greater than ourselves," for instance (105). "[I]t leads us to guess at something greater," and so proves to be an intrinsically selfless discipline (105).

F: Maybe in the course of a single experiment or day's work you are right, but for the longer term I have my doubts. "The specialization which belongs to technology," for example, "makes it difficult to see the larger picture" about ethical living (para. 110). This larger picture includes "the environment and the poor" (para. 110), neither of which appear to be the overt concern of the R\&D department you praised. So it is not true that scientists and technologists, in their professional practice, focus always on something greater than themselves. Technocrats instead build up their fields of specialty, and this "fragmentation of knowledge" makes "the broader horizon ... irrelevant" (para. 110), ethically and practically.

P: You'll have to say more than that to discredit my point. Science is a long-term, "collective task ..." (106). It breeds "solidarity," and even "makes [scientists] capable of all kinds of heroism and of devotion" (106). Are those not ethically positive traits? Indeed, scientists like myself "feel that we are working in behalf of humanity, and humanity becomes dearer to us as a result" (106).

F: Two replies. First, I hope that we do not talk at cross-purposes. We have been using "science" and "technology" interchangeably, and I hope that such use is fair. Even so, I would object that you seem to argue in a scientific vacuum, since you overlook the "economic and political life" in which "[t]he technocratic paradigm ... tends to dominate ..." (para. 109). Surely you cannot deny that today's "economy accepts every advance in technology with a view 
to profit ..." (para. 109). My point is that this "market cannot guarantee ... social inclusion" (para. 109).

P: Fine, man is man and succumbs easily to money, if that's your point. I maintain that science will see us out of the morass, or at least that "ethics and science, as they both progress, will surely adapt themselves to each other" (113). For how is the scientist to leave the 'vacuum' you mention, if he diverts his eyes from truth? "It is the love of truth even more than passion which inspires [the scientist]" (105), and my proof of this claim I present rhetorically. Ask yourself, if you will: "Is there anything which is more important [in science] than to combat lies ...?" (105). The best scientists inculcate within themselves a "concern for absolute sincerity" (105), they reject "hasty generalizations" and "fashionable" ideas (110), and hence scientists better than anyone else manage to forestall their own self-deception (105). If you'll pardon me for saying so, I feel like I am reinventing the wheel of your own, theistic, moral code, from scratch.

F: Truth does not "automatically flow from technological ... power as such" (para. 105).

P: Fair enough. But the inclusivity—aye, the catholicity—of your ethical perspective strikes me as nearly identical to the attitude of the scientific truth-seeker. Consider that science "is tending more and more to show us the mutual dependence of the different parts of the universe; to unveil its harmony to us. ... [S]cience tends towards unity and leads us towards unity. Just as it coordinates the particular laws and links them to a more general law, will it not also reduce to unity the intimate aspirations of our hearts which are seemingly so divergent, so capricious, and so alien to one another?" (108-109). 
F: Such a result and tendency might be wonderful, and focusing on the "common good" does check our "greed ..." (para. 204). The problem is that the "motive"" of technology is “"power'," to quote Romano Guardini (para. 108). He observes that via technology, "'man seizes hold of both nature and human nature'," a grip that I think our modern dependence on technology only strengthens (para. 108). Add to this state of affairs the insight that the "scientific method ... itself is already a technique of possession, mastery and transformation" (para. 106), and one can realize that within the technocratic paradigm, "[o]ur capacity for making decisions, a more genuine freedom and the space for each one's creativity are diminished" (para. 108). That outcome contradicts your thesis. What you call the 'aspirations of our hearts' are often snuffed out, not integrated, by technology.

P: Right, you're back to man's corrupt motives, attachments, and temptations. Perhaps that is the very problem with your theology of God intervening on Earth: that it has made you gaze so long at the earth. On the contrary, I think that "the God of the scientist [is] the greater the farther he withdraws from us" (105-106); when our higher truth is Indicative Truth, we have to keep looking upward and outward until we obtain it. "In our shortcomings [as human scientists], the loftiness of our ideal will sustain us" (105).

F: For the record, my Church also looks outward, "to the end of time ..." (para. 100). "[T]here is," moreover, "an infinite distance between God and the things of this world," in the sense that we certainly ought not worship nature (para. 88). But from our shared position of hindsight, ${ }^{17}$

\footnotetext{
${ }^{17}$ In this anachronistic, time-warping jail cell.
} 
the scientific ideal you allege seems not to have delivered the goods you envision. "[P] eople no longer seem to believe in a happy future; they no longer have blind trust in a better tomorrow based on the present state of the world and our technical abilities. There is a growing awareness that scientific and technological progress cannot be equated with the progress of humanity and history, a growing sense that the way to a better future lies elsewhere" (para. 113).

P: But are the people who harbor these opinions scientists? I would not expect non-scientists to grasp the profundity of what we're discussing: a quasi-moral system incidentally buoyed by scientific practice, which could someday replace people's ethics without fanfare, as a middleschooler stops believing in charm bracelets (cf. 113).

F: The point is that regardless of someone's accumulated scientific knowledge, "[s]cience and technology are not neutral" to the knower's ethical wellness (para. 114). You seem to concur when you claim that scientific practice inculcates virtue and forbids mendacity. The problem is that your divinized indicative ideal is utterly meaningless, and this meaninglessness has ethical consequences. Consider, for example, a recurring by-product of technological development: "the accumulation of constant novelties ..." (para. 113). This accumulation "exalts a superficiality which pulls us in one direction" (para. 113) toward exploitation and waste-the same direction as your ideal, Henri?

My sympathizers who are engineers might argue thusly: Are not some devices invented, in part, to achieve the ideal of 'efficiency' for its own sake? Do not some firms undertake to reduce the dimensions of a smartphone battery by one millimeter, just to become Best-in-Class in that 
dimension? ${ }^{18}$ And yet this achievement will be obsoleted in months, when "certain powerful groups" (para. 107) demand another size reduction, another marketing pitch. Granted, some improvements in efficiency help the environment, but I deny that the end always justifies the means. Within the technocratic paradigm, "[i]t becomes difficult to pause and recover depth in life"; we find that despite "a constant flood" of achievements, "the spirit of globalized technology" instills the kind of "tedious monotony" (para. 113) that technology was supposed to alleviate. We risk becoming a people that "would simply legitimate the present situation and need new forms of escapism to help us endure the emptiness" (para. 113). The poor, the environment, and our relationships suffer as a result.

P: I see. We may have reached an impasse, however, for I still suspect that a community of the science-educated and science-disciplined would treat each other as well as you like. Education is key. "Man cannot renounce knowledge without belittling himself; and that is why the interests of science are sacred" (107).

F: But "the fragmentation of knowledge and the isolation of bits of information can actually become a form of ignorance" (para. 138); we've been over this point. "Nonetheless, science and religion, with their distinctive approaches to understanding reality, can enter into an intense dialogue fruitful for both" (para. 62). Have we not accomplished that today?

Henri shuffles to the cell window, where he gazes left and right

\footnotetext{
${ }^{18}$ I conjecture this scenario from my industrial experience, where I witnessed a lot of expensive haggling over unnoticeably small cosmetic changes to under-hood components. If cell phone designers never engage in such practices, then just change the example.
} 
P: I'm still not sure that world religions and my quasi-ethics are all that different; we scientists even venerate our ancestors (106).

F: And we risk drowning the voices of such "sages" in the din of "information overload" (para. 47). Speaking of which, I have not yet asked you your crime. You were polite to ask me mine.

P: A fourth speeding ticket, in as many weeks, on my way to work. Sometimes my passion for science makes me a little reckless.

\section{EPILOGUE}

Poincaré and Francis paid their bails and went their separate ways, just as some science and engineering students pay tuition for what might be their first and last philosophy class. Are we philosophy teachers prepared to engage them? As one form of engagement, I suggest letting celebrities speak for themselves once in a while, and I am by no means the first teacher to do so. Philosopher of science James Ladyman (2002) uses contrived dialogues to teach, and Penny Weiss (2002) assigns what she calls the "Viewpoint Project," a student's analysis of an anecdote from the student's life experience, composed in the first-personal guise of an author being studied. How would that author theoretically assess that experience? I did something similar in Francis's discussion of the smartphone battery, in section III.

In the same vein, Rina Zazkis and Boris Koichu (2015) compose a fictional dialogue to dissect a heady mathematical proof, and John Atherton (1998) speaks for me and undoubtedly others when he reports that fictional dialogue assignments generate "[h]eightened attention to 
lectures, identification of central issues in a given subject, engaged imagination, and energized writing ..." (7). He also points out that "persona" writing can break through one of the negative effects of studying celebrity opinions, which is students' feeling “overwhelmed by the writer's reputation" (7). Arguing from a persona brings big names down to earth, Atherton explains, and allows students to see an author's dialectical flaws or theoretical weak points (8); the method also holds "volatile passions ... in abeyance," and prevents "exposing the student's own ego to the rude shock of criticism" (10). This buffer seems especially important for teaching the ethics of science, where ideas rather than feelings or celebrity tropes need to be debated, perhaps for the first time in a student's career.

But how do my students perform on the assignment? I do not claim to have found a pedagogical panacea. Students who struggle with analysis papers will not typically write marvelous screenplays. Even top performers tend to write dialogues that resemble jejune Twitter battles, each speaker scoring rhetorical points somewhat unrelated to their interlocutor's previous remark. As can happen in steadily-prompted class discussions, however, subtle insights do emerge. One student found Poincaré's $(1963,110)$ admonition against "hasty generalizations" hypocritical, since arguing that all of organized religion can be replaced by the virtues of the practicing scientist itself appears hasty. Another student embraced Poincaré's denial that any given piece of knowledge is inherently harmful, and found this point to ground the difference between the ethics of science and the ethics of technology. (One might respond with Rima Basu's (2019) contention that even evidence-supported belief can wrong others in the context of racism; or might ask if it neutrally affects one's temperance to know-with the aid of binoculars—how one's attractive neighbor looks while sunbathing.) Then again, many students take Francis to deliver the more relevant ethical message overall. While both Francis and 
Poincaré acknowledge the human prejudices that precipitate moral wrongdoing, one student opined that those prejudices should not be left to science to fix, and that toppling religion can be one of the harmful albeit "fashionable" kinds of ideas that Poincaré $(1963,110)$ condemns. In live discussion, students also engaged broadly on the topic of "self-deception," which both Francis and Poincaré warn against. While students may at first attribute (too) many errors in a given engineering disaster as "self-deception," pressing them to distinguish this fault from inculpable ignorance and other kinds of culpable ignorance can improve the ethical distinctions tendered in future assignments.

In closing, I recommend the Poincaré-Francis dialogue assignment, not merely to convince students that great minds can be ethically naive, but to contrast the priorities of scienceminded celebrities over a century of unparalleled technological growth. I find intriguing the thesis that ethics-of-science views, generally construed, may be a function of current technological development; and I find this possibility important for the next generation to consider, lest the views that they develop now go unexamined and appear naive in the future. To note, I do not recommend assigning student dialogues as lengthy as mine. A minimum twelveline exchange, followed by a summary paragraph in plain language, gives the students room for creativity and their interlocutors room for nuanced replies. Requiring a graded first-draft, to render the finished product more cohesive than a social media rant, may be wise. Otherwise, students who have wrestled with the dialogue can typically offer first-pass answers to the following questions:

- Was Poincaré right about ethics in his day, given the state of technology at the time? 
- Will Poincaré be proven right in our day? Is he already right? Is there a specific invention in the last 150 years that made him right, or that made him wrong? ${ }^{19}$

- How would you respond to the claim that Pope Francis argues too pessimistically against ethical outlooks like Poincaré's?

- Is there a way to fix Poincaré's thesis to ensure that the diligent pursuit of science alone can make us ethically good? Has Pope Francis, wittingly or not, identified that fix in Laudato si?

- Is there an important difference between the ethics of science and the ethics of technology?

- Do you think that Francis and Poincaré have absolutely nothing to say to each other? How do you defend that claim, considering how much pure science is needed for some technological developments?

If the semester ends, and the science student has both learned and applied the ethical views of celebrities she recognizes, then the philosophy teacher has probably made the semester jail visit worthwhile.

\footnotetext{
${ }^{19}$ I owe the specificity of this last question to XXXXXXXX.
} 


\section{References}

Atherton, John Michael. 1998. "Persona Approach Brings Philosophers and Students to Life." College Teaching 46 (1): 7-11.

Barrotta, Pierluigi. 2018. "Hume's 'Law' and the Ideal of Value-Free Science." In Scientists, Democracy and Society: A Community of Inquirers. 1-19. Springer International Publishing.

Basu, Rima. 2019. “The Wrongs of Racist Beliefs.” Philosophical Studies 176 (9): 2497-2515.

Ben-Menahem, Yemima. 2006. Conventionalism: From Poincaré to Quine. Cambridge: Cambridge University Press.

Chakravartty, Anjan. 1998. "Semirealism." Studies in the History and Philosophy of Science 29 (3): 391-408.

Condorcet, Jean-Antoine-Nicolas de Caritat, Marquis de. 1976. "Sketch for a Historical Picture of the Progress of the Human Mind." In Condorcet: Selected Writings, edited and translated by Keith Michael Baker, 209-282. Indianapolis: Bobbs-Merrill.

Daly, Anya. 2016. Merleau-Ponty and the Ethics of Intersubjectivity. Palgrave Macmillan.

Dettloff, Dean. 2017. "Catholic Air Conditioning: Laudato si' and the Overcoming of Phenomenology." The Heythrop Journal LVIII: 931-941.

Franssen, Maarten, Gert-Jan Lokhorst, and Ibo van de Poel. 2018. "Philosophy of Technology," The Stanford Encyclopedia of Philosophy (Fall 2018 Edition), Edward N. Zalta (ed.), https://plato.stanford.edu/archives/fall2018/entries/technology/

Handley, George B. 2016. "Laudato si' and the Postsecularism of the Environmental Humanities.” Environmental Humanities 8 (2): 277-284.

Iheka, Cajetan. 2017. "Pope Francis' Integral Ecology and Environmentalism for the Poor." Environmental Ethics 39: 243-259.

Ivanova, Milena. 2015. "Conventionalism about what? Where Duhem and Poincaré part ways." Studies in History and Philosophy of Science 54: 80-89.

Kelsen, Hans. 1991. "Poincaré's Conception of the Relation between Science and Morality." In General Theory of Norms, trans. Michael Hartney: 87-88. New York: Oxford University Press.

Ladyman, James. 2002. Understanding Philosophy of Science. New York: Routledge. 
McArthur, Daniel. 2006. "Recent Debates over Structural Realism.” Journal for General Philosophy of Science 37: 209-224.

McGuigan, Colin. 2019. "Wonder Opens the Heart: Pope Francis and Lisa Sideris on Nature, Encounter, and Wonder." Zygon 54 (2): 396-408.

Nix, Elizabeth. 2019. “Tuskegee Experiment: The Infamous Syphilis Study.” History, July 29, 2019. https://www.history.com/news/the-infamous-40-year-tuskegee-study.

Poincaré, Henri. 1963. "Ethics and Science." In Mathematics and Science: Last Essays, trans. John W. Bolduc: 102-113. New York: Dover Publications, Inc.

Pope Francis. 2015. Laudato si' (Praise be to you, my Lord). [Online] Available: http://w2.vatican.va/content/francesco/en/encyclicals/documents/papafrancesco_20150524_enciclica-laudato-si.html

Punzi, Vito L. 2018. "A Social Responsibility Guide for Engineering Students and Professionals of all Faith Traditions: An Overview." Sci Eng Ethics 24: 1253-1277.

Reno, R. R. 2015. "The Return of Catholic Anti-Modernism.” At First Things, https://www.firstthings.com/web-exclusives/2015/06/the-return-of-catholic-antimodernism, 18 June 2015.

Sedmak, Clemens. 2017. "Traditional Concerns, New Language? Reflections on Laudato si." The Heythrop Journal LVIII: 942-952.

Szerszynski, Bronislaw. 2016. "Praise Be to You, Earth-Beings." Environmental Humanities 8 (2): 291-297.

Vallor, Shannon. 2015. "Moral Deskilling and Upskilling in a New Machine Age: Reflections on the Ambiguous Future of Character." Philos. Technol. 28: 107-124.

Weidel, Timothy A. 2019. "Laudato Si, Marx, and a Human Motivation for Addressing Climate Change.” Environmental Ethics 41: 17-36.

Weiss, Penny A. 2002. "Making History of Ideas Classes Relevant: A Writing Strategy." Teaching Philosophy 25 (2): 123-130.

Worrall, John. 1989. "Structural Realism: the best of both worlds?” Dialectica 43 (1/2): 99-124.

Zahar, Elie. 1996. "Poincare's Structural Realism and his Logic of Discovery." In Henri Poincaré: Science and Philosophy, eds. J.-L. Greffe, G. Heinzmann \& K. Lorenz: 45-68. Berlin: Akademie Verlag.

Zazkis, Rina, and Boris Koichu. 2015. "A Fictional Dialogue on Infinitude of Primes: Introducing Virtual Duoethnography.” Educ Stud Math 88: 163-181. 